\title{
THE DISCURSIVE FORMULATION OF BREXIT: DECISION, OPPORTUNITY AND NEEDFUL AGREEMENT
}

\author{
Sadiq Almaged
}

\begin{abstract}
This study sets out to examine the British Prime Minister Theresa May's speeches delivered through her premiership. It aims to unveil the ideological discursive formation of Brexit after the referendum, and to investigate the way May squares the rhetoric to persuade the general public and the British/European political Elites to deliver the Brexit deal, though she campaigned pro-European Britain. I conduct a corpus-assisted discourse study approach, using discourse analysis methods and corpus linguistics tools for a case study of a purpose-built corpus of the Prime Minister speeches (2016-2019). The analysis revealed that the Brexit representation eschewed any identification with 'Europe' and boosted Eurosceptic sentiments by (1) rationalizing the decision to leave the European Union; (2) proposing a better future after Brexit; (3) appealing to the British people's emotion to support the Brexit deal.
\end{abstract}

\section{Keywords}

corpus-assisted discourse studies, political discourse, Brexit, legitimation strategies

\section{Introduction}

The relationship between the United Kingdom (UK) and the European Union (EU) has been uneasy, with the 'us vs them' distinction always involved. A recent volume on Brexit edited by Koller et al. (2019) Discourses of Brexit has come to the conclusion that British political discourse portrays the EU as a pragmatic union based on different values that Conservative politicians continuously argue against in their EU membership. The UK-EU's relationship has, also, been undergoing deep historical roots of Euroscepticism, which resulted in the rise of right-wing populism and the call for the Brexit referendum. The Eurosceptic ideology was driven by the opposition to the European integration and was used to "cognitively define the identity, values and goals" (van Dijk 2014: 97) of the British people. This ideology, in turn, demonized the EU and promoted the decision for Britons to leave the EU in the 2016 Brexit referendum.

Following the referendum result, the then Prime Minister (PM) David Cameron resigned and the Conservative Party appointed Theresa May as the new Party leader and PM so she can lead the Brexit deal. Throughout her premiership, she might have diverted the active cultural participation from 
positive consumption to passive production of political discourse that widened the gap between the UK and EU. Her Brexit negotiation has ignited the political conflict between the Conservative and Labour parties, broken the Scottish silence to recall independence, and put the future of the integration of whole European nations at stake.

The main aim of this study is to investigate the discursive construction of Brexit in the British PM speeches (2016-2019), and how this construction is rhetorically regulated by the type of audience Theresa May addressed across three years of her premiership. To achieve this aim, I first place Brexit in its wider socio-political context, since political speeches "should not only be defined in terms of their textual properties, but also in terms of a contextual analysis" (van Dijk 2005: 65). I, then, apply tools from Corpus linguistics (CL) to extract representative data from a large corpus of the PM's speeches for Brexit discourse analysis. Next, I qualitatively examine the discursive strategies employed by the PM to support the Brexit deal.

\section{Contextualizing Brexit: The EU-UK relation}

Since the joining of the European Economic Community (EEC) in 1973 and the EU in 1993, the UK has been a less than fully committed member of the EU. In 1974, the Labour government renegotiated the British membership in the EEC and committed to hold a referendum on the outcome (Miller 2015). When Thatcher came to power, she sought a rebate on the UK's payment to the ECC in 1984, and thought of Europe as an awkward issue to the whole UK (see Dorey 2017). In 1992, the UK left the Exchange Rate Mechanism (ERM) it joined to maintain parity of the EU exchange rate. In a more unsteady relationship with the EU, the UK left the single currency project in 1997.

When the Conservative David Cameron won the general election in 2010, he felt the increasing heat of Euroscepticism and of Eurosceptic media coverage (see Usherwood \& Startin 2012). With the role of the UK Independence Party (UKIP) and its leader Nigel Farage in the architecture of Brexit, the UK sought the referendum to leave the EU.

After 51.9 per cent of the Britons took the momentous decision to vote 'Yes' in a referendum to leave the EU in 2016, Cameron resigned and Theresa May was appointed Party Leader, not only because she was perceived to have been a successful Home Secretary, but also because she had voted Remain. However, May's rhetoric was backing up the 'leave' campaign in order to deliver the wish of the British people, portraying the EU as an antithesis of the UK's economy, as she states in one of her speeches with the President of the European Council Donald Tusk on 17 January 2017: 
This [Brexit] is an important first step towards creating a comprehensive, consistent and long-term industrial strategy that will help Britain adjust to a more globally-focused, post-Brexit economy.

The stumbling relationship between the UK and the EU has been under constant research which mostly points to that Brexit has not been a novel decision. Some Eurobarometer surveys (e.g. Eurobarometer 2013) revealed that British people expressed their high opposition to be forever integrated into the identity of the EU. The current study contributes to further our understanding of the way British politics expressed opposition to the EU and delivered Brexit through discourse.

\section{Discourse construction of social reality}

Discourse is the system of signs that constructs reality, and most of what we know about the world comes through discourse (see Loxley 2007, van Dijk 2014). Most importantly, discourse influences the way we perceive and create the world. Therefore, Discourse Analysis (DA) contributes to understanding social realities, such as Brexit in this study.

The analysis of discourse is not about the retrospective analysis of textual meaning, but also about the analysis of the creation of reality (Brexit) through discourse, convened by active subjects (Theresa May). One of the earliest conceptualizations of this form of discourse analysis was pioneered by Jurgen Habermas, whose notion of discourse is "an institutionalized way of talking that regulates and reinforces action and thereby exerts power" (Link 1983: 60). In the case of the discursive construction of Brexit, the PM can create a social reality of unfavourable EU or evil antagonist, and can persuade the Britons to support Brexit by, for instance, manipulating logic or by appealing to their emotion to foreground political ideologies.

Discourse is not only a construction of social reality (of Brexit). It is the legitimation that provides "explanations and justifications of the salient elements of the institutional tradition [...] and justifies the institutional order by giving a normative dignity to its practical imperatives" (Berger \& Luckmann 1966: 111). And, since "political discourse is identified by its actors" (van Dijk 1997: 12), the study of Theresa May's discourse contributes to understanding the (de)legitimation of Brexit, because the PM belongs to an institution of authority trying to establish the belief in its legitimacy throughout Brexit discourse. This conceptualization of discourse, according to Fairclough (1989) and Wodak (1996), is the main aim of Critical Discourse Analysis (CDA) that examines (political) discourse as one manifestation of social action. 


\section{Methodology}

\subsection{Data}

The data of this study is a purpose-built corpus comprising 205 speeches (708,147 words) delivered by Theresa May between July 2016 (when she was appointed the British PM) and March 2019 (after her failure to persuade the House of Commons to support the Withdrawal Agreement bill for the third time). These speeches, henceforth the analytic corpus of this study, were harvested from the British government website, because it is an official repository of political speeches and texts verbatim. Other websites add comments and/or extra-linguistic features, such as 'applauses' and 'greetings'. Speeches were collected under the headings 'Brexit', 'Government' and 'Theresa May', in order to limit the speeches to those related to Brexit and delivered by government officials, particularly Theresa May. She was at the top of the decision-making board (at the time of conducting this research), and had the power to influence public opinion, let alone the PM's main function as a party leader is to achieve electoral victory in the general election. The study, also, compares the analytic corpus to a reference corpus - the British National Corpus (BNC) $)^{1}-$ in order to identify the lexically salient and frequently significant keywords and topoi (see e.g. Baker 2004).

\subsection{Framework and procedures: Corpus-Assisted Discourse Studies (CADS) approach}

In this study, corpus tools and DA methods are integrated into what has been known as Corpus-Assisted Discourse Studies (CADS) approach (see e.g. Baker et al. 2008, Partington 2009). CADS provides a serendipitous journey between $\mathrm{CL}$ and CDA with the integration of external resources to build socio-cultural knowledge on the corpus (Partington 2009). During this journey, "the data itself will inevitably dictate to a considerable degree which next steps to take" (ibid.: 289). CDA, together with the statistical informing of CL, has been proven useful for examining the realization of the interdependency of language, ideology, power and politics in large corpora, which this study employs in the context of Brexit (see e.g. Baker et al. 2013, Cheng 2013, Baker \& McEnery 2015).

For their individual contribution, CL provided DA with evidence of typical linguistic patterns and tools for systematic data selection and analysis (see e.g. Baker et al. 2008, Baker et al. 2013). This has led to identifying relevant research questions and subsequent qualitative analysis. The quantitative rigour of corpus software can "facilitate the collection of normalized statistics for 
a range of linguistic features across a range of text types" (Stubbs 1994: 217). This systematicity was central in the course of Brexit discourse analysis, when different linguistic patterns identifying Brexit pervade across time. The CL tools assisted in identifying all the Brexit concordances and collocations with frequencies of occurrence. This helped me refrain from normal researchers' bias when I selected Brexit occurrences in the corpus. Furthermore, identifying all Brexit occurrences in the corpus helped reduce the criticism of data in DA being "fragmentary usually [taking] too much for granted in the way of method and of context" (Fowler 1996: 8). Another key feature of CL tools was the possibility to identify the salient lexical items (keywords) in relation to Brexit in the corpus when compared with the BNC. This provided an objective process to highlight the recurrent topoi for further DA examination (see Figure 1 and Table 2).

The corpus tools used in this study were Wmatrix (Rayson 2009) and USAS (Rayson et al. 2004). ${ }^{2}$ Wmatrix integrates part-of-speech tagging and lexical-semantic tagging to produce keyword clouds and semantic domains (see 5.1). Keyword analysis helped identify significant lexical differences between the PM's speeches (my corpus) and the BNC. To make sure all keywords do refer to Brexit in context, I have conducted Keywords In Context (KWIC) analysis, including manual reading of keywords on sentence and paragraph levels to avoid non-related texts.

Wmatrix provides a platform to access USAS - a semantic annotation tool for lexical-semantic classifications scheme that can uncover the language style and themes of the densely concentrated terms in the corpus. This tool provided a semantic coding system of words, assigning the domain ' $E$ ' for emotion words, and sub-classified them into a number of categories, such as E3 for calm/violent/ angry, E3+ for calm and E3- for violent/angry (see http://ucrel.lancs.ac.uk/ wmatrix).

For the qualitative analysis, I drew upon Halliday and Matthiessen's (2004) Systemic Functional Grammar (SFG) and van Leeuwen's (2007) legitimation strategies in the analysis of Brexit. Halliday's SFG, though not necessarily a critical perspective, assisted in labelling clause elements and identifying discourse processes of Brexit. Van Leeuwen's $(2007,2008)$ model of legitimation provides a critical way of analyzing the construction of legitimation in discourse. The fundamental function of 'legitimation' to the study of Brexit was its linguistic ability to answer the questions 'Why should we do this?' and 'Why should we do this in this way?' (van Leeuwen 2007: 93). Discourse analysts have made an influential contribution in this approach, such as Daston and Stolleis' (2010) analysis of legitimation of law and Oddo's (2011) investigation of legitimation of military action. Van Leeuwen (2008: 105-120) suggests four categories of the 
discursive construction of legitimation, namely authorization, moral evaluation, rationalization, and mythopoesis. The focus of this study was on the strategies of rationalization and moral evaluation as they have the most frequent occurrences in the representation of Brexit in the corpus.

Rationalization is legitimation by reference to reason and function of institutionalized social action, e.g. It [Brexit] is about building a new, deep and special partnership with our European friends and neighbours - because we are leaving the European Union but we are not leaving Europe. Rationalization legitimation can be instrumental, in the sense that actions are legitimized because of the benefits and positive outcomes they provide, e.g. We are determined to ensure that we get the best Brexit deal for the United Kingdom and that means it will be a deal that will ensure that we take back control of our money, of our laws, and our borders. Moral evaluation is legitimation by reference to value systems. In this type, discourse is legitimized on the bases of values (good, bad, satisfying), e.g. Our own new trade deal is one of the great opportunities of Brexit.

\section{Corpus analysis: The inside story of Brexit}

Having downloaded all the PMs' speeches on Brexit, I converted the webpages into plain text files for software analysis. The corpus comprised 205 speeches and was classified into three phases (see Table 1). The rationale behind this classification is that the manual reading of the speeches showed that each phase covered significant historical moments and was directed toward a specific audience, in order to support and deliver the Brexit deal. The first sub-corpus (henceforth, decision phase) included 27 speeches (195,645 words) delivered between 11 July 2016 while Theresa May was a candidate for Conservative Party leader and soon-to-be PM and 29 March 2017 when the UK triggered article 50. This phase was commenced with the PM's soundbite 'Brexit means Brexit' on 11 July 2016 - a declaration that remainers needed to accept and leavers needed to be reassured about. The illocutionary target ${ }^{3}$ of this phase was the British electorate 51.9 per cent of which want to be reassured that the decision to leave the EU will be honoured and 49.1 per cent of which need to be reconciled to it. Most of the speeches in this phase targeted the local audience to whom the PM was bound to 'listen to a very clear message that has come from the vote of the British people' in her speech on 28 July, 2016; 'respect the vote that took place on the 23 June' in her speech on 5 September 2016; and 'deliver the democratic decision of the British people' in her speech on 24 October 2016.

The second sub-corpus (henceforth, opportunity phase) included 91 speeches (247,373 words) delivered between 30 March 2017 and 19 March 2018 when the 
UK and EU agreed on terms for a time-limited implementation period for the UK to leave the EU. The illocutionary target of this phase was more often than not the European Council elites. The intersubjective component of the illocutionary force of the PM's speeches in this phase targeted the EU whose transition conditions left the UK closely entangled. The EU was worried that they would lose a central partner and vital market for the Union following Brexit. They often planned to punish the UK with sanctions and tax blacklists, on one hand, and to reassure a border agreement of no new checks at the Northern Ireland-Republic of Ireland borders following Brexit. This required the PM to reduce the EU's anger and reassure a better future for them (and the UK) after Brexit. This communicative act was commenced with her statement on triggering article 50 on 29 March 2017 ("we should seek to agree the terms of this future partnership alongside those of our withdrawal') and shown frequently in her speeches in the opportunity phase, such as ensuring 'the potential for future growth [as the UK leaves the EU]' in her speech on 31 August 2017; 'a bold and unique new economic partnership with the EU' in her speech on 6 October 2017; and 'each new generation should be able to build a better future' in her speech on 11 January 2018.

The third sub-corpus (henceforth, agreement phase) comprised 87 speeches (265,129 words) delivered between 20 March 2018 and 30 March 2019 when the PM made her statement on 27 of the same month that she would not lead the UK in the next stage of the Brexit negotiations, following her failure at the third attempt to persuade the House of Commons to support the Withdrawal Agreement bill. In this phase, the PM left with the burden to convince the House of Commons to pass the Brexit agreement bill. Her illocutionary target was the MPs who seemed unconvinced with the rational delivery of Brexit in the first phase, nor with the reassurance of a better future in the second phase. She drew upon the MPs emotion stating that 'community can feel the benefit [of Brexit]' in her speech on 31 December 2018; 'having established the confidence of Parliament in this government I have listened to colleagues across parliament from different parties' in her statement to the House of Commons on 21 January 2019; and 'Brexit does not belong to MPs in Parliament. It belongs to the whole country' in her speech to MPs to support the deal in Grimsby on 8 March 2019. 


\begin{tabular}{|l|c|c|c|c|}
\hline Corpus & $\begin{array}{c}\text { Jun. 2016- } \\
\text { Mar. 2017 }\end{array}$ & $\begin{array}{c}\text { Mar. 2017- } \\
\text { Mar. 2018 }\end{array}$ & $\begin{array}{c}\text { Mar. 2018- } \\
\text { Mar. 2019 }\end{array}$ & \multirow{2}{*}{ Total } \\
\hline Phase & Decision & Opportunity & Agreement & \\
\hline Speeches & 27 & 91 & 87 & 205 \\
\hline N=words & 195,645 & 247,373 & 265,129 & 708,147 \\
\hline N=Seed words & 452 & 472 & 689 & 1,613 \\
\hline Brexit & 323 & 351 & 427 & 1,101 \\
\hline withdraw* & 16 & 31 & 126 & 173 \\
\hline leave* & 113 & 90 & 136 & 339 \\
\hline
\end{tabular}

Table 1: The distribution of the PM's speeches by words, Brexit terms and phases (years)

Across the three phases, the terms Brexit, withdraw* and leave* were frequently used to refer to Brexit. I employed them as the thematic seeds of Brexit in order to drive all texts with direct reference to Brexit in the corpus. The search for these terms hits 1,912 occurrences $(1,101,214$ and 597, respectively). However, after the manual reading of these terms in context, 173 occurrences of withdraw* and 339 of leave* referred to Brexit in context, which downsized the total number to 1,613 occurrences of Brexit-related terms (see Table 1).

Several discursive features were uncovered in the analysis which provided whole corpus evidence for the discourse construction of Brexit. Overall, the analysis of the PM's discourse practices across the three phases showed that the discourse on Brexit was characterized by, most ubiquitously, rationalizing the decision to leave the EU (5.1), proposing a better future (5.2), and appealing to emotions (5.3). Though they achieve the same goal (leaving the EU), in what follows, each of the discourse practices is discussed independently, with the analytical observations set out first and, then, embedded within a wider purview of CDA.

\subsection{Rationalizing the decision to leave the $\mathrm{EU}$}

The more prevailing legitimation strategy in the corpus was rationalization. The strategy of legitimizing Brexit in terms of reason was shown to be a typical feature of the British PM's mechanism in critical situations. The PM frequently relied on rationality to justify Brexit, particularly in the first phase (decision), coming to terms with the referendum result and the local audience of her speeches. She wanted to convince Brexiters and pro-Europeans of the collective enterprise to leave the EU. Her slogan 'Brexit means Brexit' coined on 11 July 2016 was a declaration that remainers like herself needed to accept and leavers needed to be reassured about. 
This was visible when 360 occurrences (79.64\%) of the total number of the occurrences of Brexit, withdraw* and leave* in the decision phase presented the decision to leave the EU as a reason-based necessity, rather than an "arbitrary manifestation of a personal will", as Steffek (2009: 314) states in his analysis of discursive legitimation in environmental governance. Brexit was presented as part of the British people's 'sociocultural conceptualization' that provides a link between language and culture and identifies what is being naturalized (Silverstein 2004: 621) - Britain is no longer part of the EU. This 'ideological discursive formations' (of Brexit), in turn, presented the issue as common sense in discourse (Fairclough 2001: 76). Consider Examples 1 and 2:

The reason I've been saying Brexit means Brexit is precisely because it does, and to be very clear that we are going to deliver on the wishes of the British people. (Theresa May's speech at the G20 Summit press conference on 5 September 2016)

(2) Our objectives include a proposed free trade agreement between Britain and the European Union [which] means more trade, and more trade means more jobs and more wealth creation. (Theresa May's speech at the London's Lancaster House on 17 January 2017)

As Example 1 illustrates, the reason the PM sets to leave the EU is to deliver on the wish of the British people. This rationality supports the democratic decision British people took in the referendum, on one hand, and persuades pro-EU to rethink the leave, on the other hand. In Example 2, the reason to leave the EU is economically presented, such as to have more jobs and more wealth creation resulted from a free trade agreement. This finding implies that the EU was impeding the economic growth and good relations with the UK. This Eurosceptic vision is cognitively legitimized on the bases of 'comprehensibility and taken-for-grantedness outcomes' (see Suchman 1995: 571) that the British people will have a better economy/relationship with Europe, out of the EU.

A KWIC analysis of the decision phase (first sub-corpus) provided evidence that a large number of rationalization legitimation of Brexit was frequently goal-oriented instrumental, i.e. delivering Brexit was for the positive outcomes or benefits, as in Example 2, to have more jobs and more wealth creation. Similar findings have been reported by Vaara et al. (2006: 794) in their analysis of the legitimation actions of industrial restructuring, where "society has constructed to endow them with cognitive validity". This traditionally reflects the philosophy of utilitarianism which argues for purposefulness in legitimizing actions, even though those actions would cause harm in some other directions, such as immigration and trade. 
A noteworthy finding in the discourse construction of Brexit is that the keyword analysis, using WMatrix, showed that the top ten keywords in the whole corpus, as shown by their LogRatio, mostly referred to normal political participants/reasons to deliver Brexit (see Figure 1, Table 1). This is expected in the context of political discourse, particularly speeches delivered by the elite member of the government.

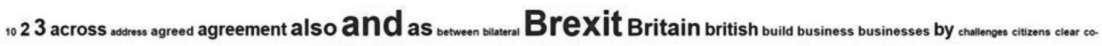

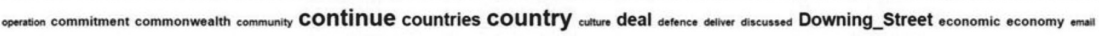

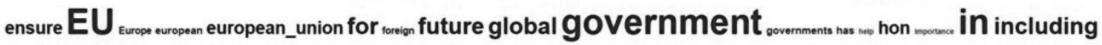

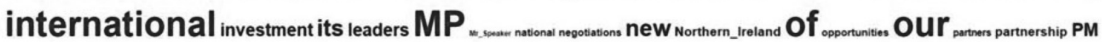

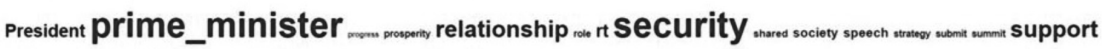
the their $_{\text {Theresa_May to }}$ today $_{\text {trade }}$ UK uks United_kingdom values van $_{\text {Will }}$ wat world

Figure 1: 'Brexit' keyword clouds in the whole corpus

As illustrated in Figure 1, the frequent political participants in bold are UK, Theresa_May, EU, Brexit, prime_minister, MP, security, government, international and future. The statistics of their frequency are provided in Table 2.

\begin{tabular}{|l|l|l|l|l|}
\hline No. & Keywords & Frequency & LL & LogRatio \\
\hline 1. & UK & 3,668 & $6,759.18$ & 13.44 \\
\hline 2. & Theresa_May & 1,659 & $3,057.11$ & 12.29 \\
\hline 3. & EU & 1,583 & $2,917.06$ & 12.23 \\
\hline 4. & Brexit & 923 & $1,700.85$ & 11.45 \\
\hline 5. & prime_minister & 3,647 & $6,674.91$ & 10.84 \\
\hline 6. & MP & 1,334 & $2,418.67$ & 9.39 \\
\hline 7. & security & 1,459 & $2,405.24$ & 6.06 \\
\hline 8. & government & 1,759 & $2,310.43$ & 4.07 \\
\hline 9. & international & 1,196 & $1,903.16$ & 5.57 \\
\hline 10. & future & 1,227 & $1,569.69$ & 3.94 \\
\hline
\end{tabular}

Table 2: Top ten 'Brexit' keywords in the whole corpus

Yet, the KWIC analysis of the top ten keywords revealed that among the normal political reason/participants in delivering Brexit were 'security' (frequently delivered in phase one) and 'future' (mostly delivered in phase two, see 5.2). As indicated by its LogRatio, the frequency of use of 'security' in the corpus is over 44 times higher than in the BNC, as illustrated in Example 3: 
(3) I want the [Brexit] deal we negotiate to reflect the kind of mature, co-operative relationship that close friends and allies enjoy. A deal that will deliver the deepest possible co-operation to ensure our national security and the security of our allies. (Theresa May's statement on the issues discussed at European Council on 19 December 2016)

In this extract, the PM presents the Brexit deal as a key issue for the security of the UK and other EU countries. Security was connected to post-Brexit plans, and was not a 'central feature' of pre-referendum Brexit campaign in 2016. This may indicate a deceptive or otherwise inattentive political move through which Brexiters overlooked security. On the other hand, reconsidering UK security after Brexit brings to surface the limited military capabilities of the UK in confronting (inter)national security issues. This connection between security and post-Brexit was also reported in Koppa's (2019) investigation of the relationship between the Common Security/Defence Policy and the North Atlantic Treaty Organization (NATO). She showed that security is a central feature of post-Brexit negotiations and strategic concern on the UK military capabilities that might be most affected by Brexit.

\subsection{Proposing a better future}

Portraying the UK a better place after Brexit emerged as a salient discursive practice in the second sub-corpus (opportunity phase), deployed by the keyword 'future' in the PM's speeches between 30 March 2017 and 19 March 2018 (see Table 2). In this phase, the PM's speeches were directed toward the European Council to ratify the agreement and not to try to punish the UK, following the trigger of Article 50 on 29 March 2017 and starting a two-year process to leave the EU. The 245 occurrences (52\%) of Brexit, withdraw* and leave* rationalized the deal on the bases of British political optimism regarding the positive UK-Europe relationship and economy after Brexit. The PM reassured enhanced EU-UK relationship to curb the EU fear of losing partners and trade markets. The KWIC analysis of the lexico-syntactic features of 'future' keyword showed that the linguistic realization of proposing a better future was made frequently through adjectives (e.g. possible), nouns (e.g. future) and modal verbs (e.g. will). In her speech to the Mansion House, May set out her vision on the EU-UK relationship after Brexit, as illustrated in Examples 4 and 5:

(4) We will have exactly the same rules and regulations as the EU, as our EU Withdrawal Bill will ensure they are carried over into our domestic law. (Theresa May's speech at 20th anniversary of Bank of England independence event on 27 September, July 2017) 
The UK will need to make a strong commitment that its regulatory standards will remain as high as the EU's. That commitment, in practice, will mean that UK and $E U$ regulatory standards will remain substantially similar in the future. (Theresa May's speech on future UK-EU relations at the Mansion House on 2 March 2018)

As in Examples 4 and 5, the modal verb will was frequently used in the representation of Brexit. Will was mostly an example of epistemic modality expressing a weak commitment to the degree of the truth of the proposition (see Simpson 1993). While it can show certainty in certain situations, will remained epistemic relying on May's knowledge and future expectations of the Brexit deal rather than the obligation of laws and conventions (see also Bednarek 2006). This means that the PM is not surely confident that Britain 'will have exactly the same rules and regulations as the EU, nor to make a strong commitment to the Brexit deal, or that the $U K$ and EU regulatory standards will remain substantially similar in the future'. This is in contrast to the infrequent use of positive/negative deontic modality that characterizes the speakers' degree of obligation in certain actions, such as the use of (Britain must (not) .....) as a deontic necessity conveying the highest degree of obligation of a command in (e.g. Britain must face up to a period of momentous change. It means we must go through a tough negotiation and forge a new role for ourselves in the world, May speaking at Davos on 19 January 2017). Epistemic will is also different from non-categorical modality (e.g. Britain is (not) ...) showing the strongest degree of commitment (see Simpson 1993), such as Britain is doing with the lowest corporation tax in the G7, May speaking to India-UK Tech Summit on 9 November 2016). This lack of confidence in the truth of the UK's future expressed by the PM could have been contributed to the rejection of the deal in the House of Commons on 15 January and on 12 March 2019.

Unlike the disposition of a better future, in a number of examples, there was the fear that Britain's future will be crafted by the European countries. This fear implied issues of uncertainty on, such as the UK borders and free markets with other EU countries, as illustrated in Example 6:

(6) Brexit will never stop us from having a very high level of cooperation between our two countries. It can create uncertainty on some subjects in the short term, but I think that our responsibility is to be able to manage this complexity and to be determined to improve the situation on each side of our border [...] We will reinforce the security infrastructure with extra CCTV, fencing and infra-red technology at Calais and other border points. (Theresa May's speech at the UK-France Summit on 18 January 2018) 
In Example 6, the PM expresses her fear of uncertainty over the UK future in her speech at the UK-France Summit. However, she tried to dispel this fear by the reassurance of cooperation with neighbouring countries and better security on the borders. This confirms similar findings of the lack of certainty in the UK-EU relationship after Brexit by Hantzsche et al. (2018). They found that in addition to its economic impact, Brexit affects confidence and provokes a lack of trust in the trading relationship and longer-run economy between the UK and EU.

\subsection{Appealing to Emotion}

While evidence for rationalizing Brexit deal showed in considerable density in the first (decision) and second (opportunity) phases, a close inspection of the PM's speeches between 20 March 2018 and 30 March 2019 revealed that the appeal to moral evaluation (emotion) to legitimize Brexit was deployed intensively in the agreement phase (third sub-corpus). The drawing on reason did not enable the PM to get the withdrawal bill passed in the House of Commons, which might drive her to direct her speeches toward the MPs, who rejected the withdrawal bill for a third time on 29 March 2019. Albeit not enough for it to pass, the MPs did not respect themselves by voting leave, but the fear of losing Brexit. In 447 occurrences (65\%) of Brexit, withdraw* and leave* in this phase, emotion was used to legitimize Brexit. Emotional discourse underpins influential ideologies that, according to Kassab (2016), entail strategic employment of emotion to actively foreground political ideologies that necessitate people's confidence and right-mindedness. Similar findings have been reported by discourse analysts (e.g. Johnson et al. 2006, Lavrusheva 2013) who find that legitimation through emotional discourse links political institutions to cultural beliefs and values, hence gaining people's confidence. The findings confirmed this connection when the PM tried to recover the value of the British identity by seeking support for the Brexit deal. Consider Examples 7 and 8:

(7) I know Members across the House are genuinely worried that time is running out, that if the Government doesn't come back with a further meaningful vote or it loses that vote, Parliament won't have time to make its voice heard on the next steps. I know too that members across the House are deeply concerned by the effect of the current uncertainty on businesses. (Theresa May's statement to the House of Commons on 26 February 2019)

(8) The ability to develop our own new trade deals is one of the great opportunities of Brexit. (Theresa May's Commons statement following European Council on 22 October 2018). 
Speaking to the House of Commons, in Example 7, the underlying factivity of 'know' (see Dudley et al. 2017) is to commit to the truth of the proposition that MPs are emotionally 'worried' if the vote is not passed in the House of Commons. May creates the feeling that it is vital to vote for the agreement bill, supported by the proposed 'fact' that 'members of the House are deeply concerned by the effect of the current uncertainty on businesses' if they fail to pass the bill. Also, May's use of 'great' to intensify the Brexit outcomes to the level of great opportunities in Example 8 is a process of lexical intensification that shows a high degree of emotions to stimulate the hearer's attention. A similar finding has been reported by Partington (1993: 178) in his corpus analysis that intensification has the communicative value of, among many, "persuading [and] influencing the listener's reception of the message". Within this emotional discourse, May is seen playing identity politics (see Wilkinson 2017) in the sense that she explains Eurosceptic beliefs and priorities of 'who we are' and 'who you are'. As put by the Guardian columnist Fintan O'Toole (2016), "Brexit is an English Nationalist movement". This construction of 'us', as in Example 8 our own new trade deals constructs the social connection to a group and contributes the emotional appeal of the discourse. It is animated by the passion of English nationalism, looking for an independent England. This insistence on 'Englishness' has been confirmed by several post-referendum socio-political studies. For example, Henderson et al. (2016) find a connection between being an English nationalist and Euroscepticism in results from a number of polls (including eleven English polls, twenty Scottish polls, five from Wales and three from Northern Ireland). These findings remain true in the light that identity matters over economic issues (see e.g. Corbett 2017).

May's construction of monolithic British people based on group identity still has a strategic conflation of exclusive and inclusive 'we'. May showed that the decision on Brexit is exercised by a group of political actors (MPs) and certainly not by members of the general public, as in Example 7 (I know Members across the House are genuinely worried ... and Parliament won't have time to make its voice...).

More subtle, but deploying the evidence of a considerable density of violence and anger in discussing Brexit was the PM's lexical selection of, for example, force, fight, threat. To map the PM's emotional discourse, I tagged the corpus for semantic annotation using USAS (see 4.2.2). The KWIC analysis of the semantic tagset of emotion (E) showed that the PM was frequently violent and angry (E3-, word count $=1,388$ ) in her discourse, in comparison with being worry/confident $(E 6$, word count $=752)$ and brave/scared $(E 5$, word count $=334)$, as illustrated in Figure 2: 


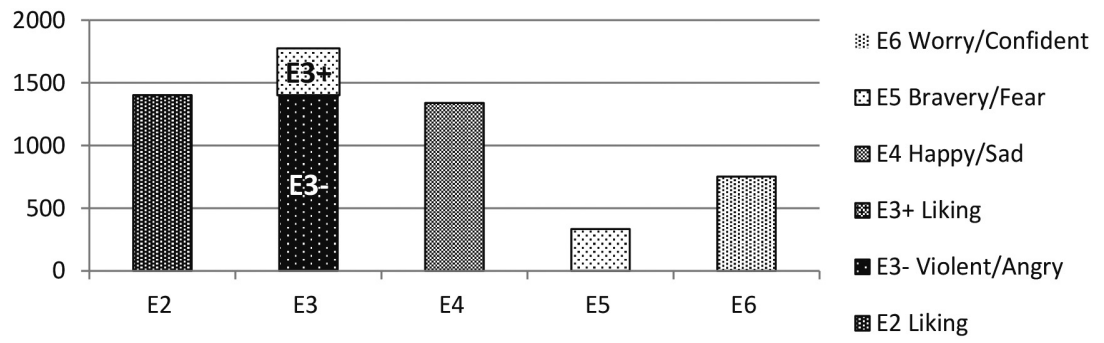

Figure 2: Semantic tagset of the category of Emotion (E) in the third (agreement) corpus

The PM's violent/angry emotions in the agreement phase (third sub-corpus) might be due to her being unable to get support for her Brexit deal in the House of Commons. She frequently evoked a sense of fear by warning the MPs of the sequences of not leaving the EU, with the intention to deliver Brexit deal. This emotional intentionality (see Searle 2001) was linguistically realized through a large number of warning speech acts. Consider Example 9 when Theresa May addressed Conservative MPs, journalists and business leaders at Grimsby urging the vote for the withdrawal agreement bill:

(9) Back it and the UK will leave the European Union. Reject it and no one knows what will happen [...] The prolonged uncertainty would threaten jobs and investment and it would mean months more arguing about Brexit when we should be focusing on the other issues people in Grimsby care about like our NHS, schools, policing and housing. (Theresa May's speech in Grimsby ahead of the second vote on Brexit deal on 8 March 2019)

May appealed to the MPs' emotion and threatened losing jobs if the MPs do not back the Brexit deal she has negotiated with the EU. The expectation of threat/fear in Example 9 would threaten jobs and investment is central to the creation of a 'risk society'- a concept first introduced by the sociologist Ulrich Beck (1992) to refer to a modern society that organizes in response to risk and broadens the conflict between capital and labour. In such a society, security becomes the responsibility of individuals and communities, which adds much threat/fear to their living conditions. Among the risks the PM warned was the immigration (crisis), another emotional script May appealed to, to deliver Brexit, as Example 10 illustrates: 
(10) Once we have left the EU, we will be fully in control of who comes here. It will no longer be the case that EU nationals, regardless of the skills or experience they have to offer, can jump the queue ahead of engineers from Sydney or software developers from Delhi. (Theresa May, November 2018)

In Example 10, speaking to the Confederation of British Industry (CBI), the PM warned of the surge in the number of EU immigrants working in the UK and promised to codify who enters the UK regardless of the skill they have. Immigrants were portrayed not only as others and intruders, but also as unqualified people to live in the UK albeit having skills. This British self-centered tone fuels Euroscepticism and inspires 'English identity' fighters. This is an argumentative strategy by which political leaders justify the 'demonization of others' (Wodak 2001: 72), particularly in fear situations when emotions are appealed to for legitimizing their discourse, which also contributes to the construction of 'us' in emotional appeal of the discourse.

\section{Conclusion}

This study aimed to identify the discursive construction of Brexit, with the focus on the legitimation strategies employed by the British PM to deliver Brexit in her premiership (2016-2019). Following a multidisciplinary approach, integrating CL tools and DA methods, I have characterized a regular performance of three discourse practices, namely (1) rationalizing the decision to leave the EU, particularly in speeches delivered in the decision phase; (2) proposing a better future for the UK after leaving the EU in the opportunity phase; and (3) appealing to people's emotion to support the deal in the agreement phase. The perlocutionary effect of discourse deployed within these practices and phases was to have Britons accept the current Brexit proposals, no matter what the damage it causes to the UK, and for the PM to support the deal in the House of Commons. The analysis showed that while the first phase was arguably successful on the bases of rationalizing Brexit and coming to terms with the referendum result, the second phase ended with an unsupported proposal when May turned to the European Elites to ratify the deal in the face of better future for the UK and EU. The final phase showed the PM's failure at the third attempt to persuade the House of Commons by appealing to their emotions to support the Withdrawal Agreement bill on 29 March 2019, followed by her resignation as leader of the Conservative Party on 7 June and as Prime Minister on 24 July 2019.

Corpus software Wmatrix and USAS allowed building up keyword clouds and semantic categories of an array of lexis that helped characterize the discursive strategies in legitimizing Brexit, namely rationalization and moral evaluation. Yet, 
the statistical tools provided limited insight into the ways Brexit was legitimized in my corpus. Therefore, KWIC analysis was used, including a manual reading of concordance lines and collocations of Brexit keywords. The analysis revealed that the verbal release of the rational legitimation of Brexit was goal-oriented instrumental, such as characterizing the positive outcomes of leaving the EU to rebuild the UK-Europe relations (including trade and investment) and to maintain UK security in speeches delivered in the decision phase (June 2016-March 2017). Proposing a better future out of the EU emerged as a frequent rational legitimation of Brexit in speeches delivered in the opportunity phase (March 2017-March 2018). These findings showed that economy and security were top critical issues in the UK. This, in part, refutes previous reports that Brexiters have barely featured complex Brexit consequences and have underestimated the true impact of leaving the EU (see e.g. Felbermayr et al. 2017).

A close analysis of the semantic tagset of Brexit discourse uncovered that the PM appealed to moral evaluation to legitimize Brexit in the agreement phase (March 2018-March 2019). This finding supports the view that emotional legitimation can be used in influential situations, such as fear from outsiders, death and destruction (see e.g. Chilton 2004). The analysis, also, showed that identity was conceptualized as a discursive construction when the PM recreated a fundamental separation between the UK and EU, representing the later as a different 'other'. This constructs the reality of the English identity over economic loss portraying Britons as identity losers under the EU alliance. This confirmed similar findings that Britons' attitude toward the EU was tied to national identities, which eschewed any identification with 'Europe' and boosted Eurosceptic sentiments (see e.g. Gifford 2014, Dorey 2017). The analysis also showed the growing use of violent/angry language by the PM in representing Brexit in the agreement phase. Although this emotional discourse is a characteristic of political power (see e.g. Bernstein 2011), it might be due to her being unable to gain Parliamentary support for the Brexit withdrawal bill in the House of Commons. In consequence, the PM's utilization of rationality and emotion to legitimize Brexit has not the potential to divert the anti-Brexiters decision-making to accept the deal, neither to bridge the pro-Brexit alliances, who have not put full support for the deal in the House of Commons.

\section{Notes}

1100 million word corpus of written and spoken English (www.natcorp.ox.ac.uk/).

2 Wmatrix and USAS (UCREL Semantic Analysis System) can be reached at $<$ http://ucrel.lancs. ac.uk/wmatrix/>.

3 For more information on illocutionary target, see Gramming (2002) and Grundy (2020). 


\section{References}

Baker, P. (2004) 'Querying keywords : Questions of difference, frequency and sense in keywords analysis.' Journal of English Linguistics 32(4), 346-359.

Baker, P. and McEnery, T. (2015) 'Who benefits when discourse gets democratised?: Analysing a Twitter corpus around the British Benefits Street debate.' In: Baker, P. and McEnery, T. (eds) Corpora and Discourse Studies: Integrating Discourse and Corpora. London: Palgrave Macmillan. 244-266.

Baker, P., Gabrielatos, C. and McEnery, T. (2013) Discourse Analysis and Media Attitudes: The Representation of Islam in the British Press. Cambridge: Cambridge University Press.

Baker, P., Gabrielatos, C., KhosraviNik, M., Krzyzanowski, M., McEnery, T. and Wodak, R. (2008) 'A useful methodological synergy? Combining critical discourse analysis and corpus linguistics to examine discourses of refugees and asylum seekers in the UK press.' Discourse \& Society 19, 273-306.

Beck, U. (1992) Risk Society: Towards a New Modernity. London: Sage.

Bednarek, M. (2006) Evaluation in Media Discourse. London: Continuum.

Berger, P. and Luckmann, T. (1966) The Social Construction of Reality. Harmondsworth, England: Penguin.

Bernstein, R. (2011) 'Hannah Arendt's reflections on violence and power.' IRIS 3(5), 3-30.

Cheng, W. (2013) 'Corpus-based linguistic approaches to critical discourse analysis.' In: Chapelle, C. (ed.) The Encyclopedia of Applied Linguistics. London: Blackwell. 1-8.

Chilton, P. (2004) Analysing Political Discourse: Theory and Practice. London: Routledge.

Corbett, S. (2017) 'The social consequences of Brexit for the UK and Europe: Euroscepticism, populism, nationalism, and societal division.' International Journal of Social Quality 6(1), 11-31.

Daston, L. and Stolleis, M. (2010) 'Natural law and laws of nature in early modern Europe: Jurisprudence, theology, moral and natural philosophy.' The British Journal for the History of Science 43(1), 123-124.

Dorey, P. (2017) 'Towards exit from the EU: The Conservative Party's increasing Euroscepticism since the 1980s.' Politics and Governance 5(2), 27-40.

Dudley, R., Rowe, M., Hacquard, V., and Lidz, J. (2017) 'Discovering the factivity of know.' Proceedings of SALT 27, 600-619.

Eurobarometer (2013) Standard Eurobarometer. (Report No. 80: Autumn). Brussels: European Commission. Retrieved from $<$ http://ec.europa.eu/public_opinion/archives/ eb/eb80/eb80 publ en.pdf>.

Fairclough, N. (1989) Language and Power. London: Longman.

Fairclough, N. (2001) 'Critical discourse analysis as a method in social scientific research.' In: Wodak, R. and Meyer, M. (eds) Methods of Critical Discourse Analysis. London: Thousand Oaks. 121-138.

Felbermayr, G., Clement, F., Gröschl, J. and Stöhlke, D. (2017) 'Economic effects of Brexit on the European economy.' EconPol 1, 1-42.

Fowler, R. (1996) 'On critical linguistics.' In: Gumperz, J. and Levinson, C. (eds) Rethinking Linguistic Relativity. Cambridge: Cambridge University Press. 3-14.

Gifford, C. (2014) The Making of Eurosceptic Britain. Hampshire: Ashgate.

Gramming, T. (2002) Technical Knowledge and Development. Observing Aid Projects and Processes. London: Routledge.

Grundy, P. (2020) Doing Pragmatics. $4^{\text {th }}$ ed. London: Routledge. 
Halliday, M. A. K. and Matthiessen, C. (2004) An Introduction to Functional Grammar. $3^{\text {rd }}$ ed. London: Arnold.

Hantzsche, A., Kara, A. and Young, G. (2018) 'The economic effects of the UK government's proposed Brexit deal.' The World Economy 42, 5-20.

Henderson, A., Jeffery, C., Liñeira, R., Scully, R., Wincott, D. and Jones, W. (2016) 'England, Englishness and Brexit.' The Political Quarterly 87(2), 187-199.

Johnson, C., Dowd, J. T. and Ridgeway, C. (2006) 'Legitimacy as a social process.' Annual Review of Sociology 32, 53-78.

Kassab, H. (2016) The Power of Emotion in Politics, Philosophy, and Ideology. UK: Palgrave Macmillan.

Koller, V., Kopf, S. and Miglbauer, M. (2019) Discourses of Brexit. London: Routledge.

Koppa, M. (2019, April) The Relationship between CSDP and NATO after Brexit and the EU Global Strategy. Panteion University of Athens. Foundation for European Progressive Studies (FEPS).

Lavrusheva, O. (2013) Discursive Legitimation Strategies in the Media. Case Study of the UK Retail Planning Policy (Master's thesis). Markkinoinnin laitos Department of Marketing. Retrieved from <http://urn.fi/URN:NBN:fi:aalto-201403171569>.

Link, J. (1983) Was ist und was bringt Diskurstaktik. KulturRRevolution 2, 60-66.

Loxley, J. (2007) Performativity. London: Routledge.

Miller, V. (2015) The 1974-75 UK Renegotiation of EEC Membership and Referendum $U K$ (7253). UK: The House of Commons Library.

Oddo, J. (2011) 'War legitimation discourse: Representing 'Us' and 'Them' in four US presidential addresses.' Discourse and Society 22(3), 287-314.

O'Toole, F. (2016, June 19) Brexit is being driven by English nationalism. And it will end in self-rule. The Guardian. Retrieved on March 12, 2019, <https://www.theguardian. com/commentisfree/2016/jun/18/england-eu-referendum-brexit>.

Partington, A. (1993) 'Corpus evidence of language change: The case of intensifier.' In: Baker, M., Francis, G., and Tognini-Bonelli, E. (eds) Text and Technology. Amsterdam: John Benjamins. 177-192.

Partington, A. (2009) 'Evaluating evaluation and some concluding thoughts on CADS.' In: Morley, J. and Bayley, P. (eds) Corpus-assisted Discourse Studies on the Iraq Conflict: Wording the War. London: Routledge. 261-304.

Rayson, P. (2008) 'From key words to key semantic domains.' International Journal of Corpus Linguistics 13(4), 519-549.

Rayson, P., Archer, D., Piao, S. and McEnery, T. (2004, May) 'The UCREL semantic analysis system.' Proceedings of the workshop on Beyond Named Entity Recognition Semantic labelling for NLP tasks in association with 4th International Conference on Language Resources and Evaluation (LREC). Lisbon: Centro Cultural de Belem. $7-12$.

Searle, J. (2001) Rationality in Action. Massachusetts: MIT Press.

Silverstein, M. (2004) "CCultural" concepts and the language-culture nexus.' Current Anthropology 45(5), 621-652.

Simpson, P. (1993) Language, Ideology and Point of View. London, Routledge.

Steffek, J. (2009) 'Discursive legitimation in environmental governance.' Forest Policy and Economics 11, 313-318.

Stubbs, M. (1994) 'Grammar, text and ideology.' Applied Linguistics 15(2), 201-23.

Suchman, M. (1995) 'Managing legitimacy: Strategic and institutional approaches.' The Academy of Management Review 20(3), 571-610. 
Usherwood, S. and Startin, N. (2012) 'Euroscepticism as a persistent phenomenon.' Journal of Common Market Studies 51(1), 1-16.

Vaara, E., Tienari, J. and Laurila, J. (2006) 'Pulp and paper fiction: On the discursive legitimation of global industrial restructuring.' Organization Studies 27(6), 789-810.

van Dijk, T. A. (1997) 'What is political discourse analysis?' Key-note address Congress Political Linguistics.' In: Blommaert, J. and Bulcaen, C. (eds) Political Linguistics. Amsterdam: John Benjamins. 11-52.

van Dijk, T. A. (2005) 'War rhetoric of a little ally: Political implicatures and Aznar's legitimatization of the war in Iraq.' Journal of Language and Politics 4(1), 65-92.

van Dijk, T. A. (2014) Discourse and Knowledge. Cambridge: Cambridge University Press.

van Leeuwen, T. (2007) 'Legitimation in discourse and communication.' Discourse and Communication 1(1), 91-112.

van Leeuwen, T. (2008) Discourse and Practice: New Tools for Critical Discourse Analysis. Oxford: Oxford University Press.

Wilkinson, A. (2017, May 11) Theresa May is playing 'identity politics' more adeptly than the left. The Guardian. Retrieved on January 23, 2020, <https://www.theguardian. $\mathrm{com} /$ commentisfree/2017/may/11/theresa-may-identity-politics-tory-patrioticbritish-policies>.

Wodak, R. (1996) Disorders of Discourse. London: Longman.

Wodak, R. (2001) 'The discourse-historical approach.' In: Wodak, R. and Meyer, M. (eds) Methods of Critical Discourse Analysis. London: Sage. 63-94.

Sadiq Almaged is Associate Professor of English Linguistics at University of Thiqar, Iraq. He is affiliated with Swansea University, UK, where he got his MPhil and $\mathrm{PhD}$ in English linguistics. His main researches focus on discourse analysis, corpus linguistics, textual functions and ideological representations of language and culture within discourse. He is currently conducting research on international security discourse, to find out how discourses of threat construct the political identity of states and map (counter)terrorism agendas, with consequences for foreign policies involving security. Almaged has presented his research at local conferences in the UK and international conferences in France, Hungary, Turkey and Italy and has published several journal articles and book chapters.

Address: Sadiq Almaged, Department of English, Thiqar University, Almustafawia, 64001, Iraq. [e-mail: sadiq.a@utq.edu.iq]. Affiliation: Swansea University, Department of English, UK, 3 Fleet St, Swansea, SA1 3UX. [e-mail: 800668@swansea.ac.uk]. 